Pak. j. sci. ind. res. Ser. A: phys. sci. 201255 (2) 86-91

\title{
Characterization and Fatty Acid Distribution in the Lipids of Leucaena leucocephala and Prosopis africana
}

\author{
Adewale Adewuyi* and Rotimi Ayodele Oderinde \\ Industrial Unit, Department of Chemistry, University of Ibadan, Ibadan, Oyo State, Nigeria
}

(received May 10, 2010; revised February 20, 2011; accepted April 30, 2011)

\begin{abstract}
The seed oils from Leucaena leucocephala and Prosopis africana were evaluated for their chemical composition, mineral metals and fatty acid composition. The mineral metal and proximate composition of their seeds were also checked. The oil yield of the seed of $L$. leucocephala was found to be $6.80 \pm 0.71 \mathrm{~g} / 100 \mathrm{~g}$ of seed while that of P. africana was $4.22 \pm 0.40 \mathrm{~g} / 100 \mathrm{~g}$ of seed. The crude protein was higher in L. leucocephala ( $45.40 \pm 0.60 \mathrm{~g} / 100 \mathrm{~g}$ of seed) than $P$. africana $(40.20 \pm 0.80 \mathrm{~g} / 100 \mathrm{~g}$ of seed). The moisture content was also found lower in L. leucocephala $(2.10 \pm 0.20 \mathrm{~g} / 100 \mathrm{~g}$ of seed) than in P. africana $(3.00 \pm 0.40 \mathrm{~g} / 100 \mathrm{~g}$ of seed). $\mathrm{K}$ was found to be most abundant in the seed as well as the oils of $L$. leucocephala and $P$. africana while $\mathrm{Cd}$ had the least concentration in both seeds and oils. The iodine value of $L$. leucocephala was $113.00 \pm 2.10 \mathrm{~g} / 100 \mathrm{~g}$ while that of $P$. africana was $118.30 \pm$ $1.00 \mathrm{~g} / 100 \mathrm{~g}$. Neutral lipids were the dominant lipid class in both L. leucocephala and P. africana. Linoleic acid was the dominant fatty acid (C18:2) in L. leucocephala while oleic (C18:1) was the dominant fatty acid found in P. africana.
\end{abstract}

Keywords: fatty acids, Leucaena leucocephala, lipid classes, mineral metals, Prosopis africana

\section{Introduction}

Seed oils are mainly triacylglycerols. They are usually named by their biological sources (such as soybean oil, palm oils etc) which have range of physical and chemical compositional parameters by which it can be recognized. They have different applications which are dependent on these physical and chemical compositional parameters (Frank, 2004). The physico-chemical properties of seed oils need to be determined so as to make the best use of the seed oils (Akoh and Min, 2002).

Many tropical seed oils can not be utilized due to insufficient information of their properties and composition.

Leucaena leucocephala and Prosopis africana are legumes belonging to the Mimosoideae family. They form a part of the natural vegetation of western Nigeria. Prosopis africana is a tree of about $24 \mathrm{~m}$ high. It has a dense spreading crown bearing clusters of yellow flowers and reddish brown pods. It is very suitable as shade-tree in gardens and roadsides. Propagation of the seed is slow but germination can be accelerated by seed treatment. Leucaena leucocephala is a shrub or small

*Author for correspondence; E-mail: walexy62@yahoo.com tree of about $15 \mathrm{~m}$ high, grown as an ornamental plant. It makes a sound hedge, wind-break and shade-plant for plantation crops. It fixes nitrogen and its leave-fall returns a significant amount of nutrient to the ground (Burkill, 1995).

Leucaena leucocephala and Prosopis africana belong to this group of indigenous tropical plants with meagre information on the composition of their seed and seed oils. In the present study, the oils from Leucaena leucocephala and Prosopis africana were evaluated for their physico-chemical properties, mineral metal composition, fatty acid composition and distribution in their different lipids classes. The proximate composition as well as the mineral metal contents of their seeds were also studied.

\section{Materials and Methods}

Materials. The seed samples were obtained from the environment of the University of Ibadan, Oyo State, Nigeria. They were identified at the herbarium unit, Botany Department, University of Ibadan. The whole seed was subsequently ground in a laboratory mill (Gallenkamph, 82942, Brit. Pat, England) and stored in a cellophane bag at $4{ }^{\circ} \mathrm{C}$ prior to analysis. Silica gel 
(60 -120 mesh) was purchased from Acme Synthesis Chemicals, Mumbai. This was further activated by heating in an air oven at $110^{\circ} \mathrm{C}$ for $2 \mathrm{~h}$ before being used for column chromatography. All solvents and chemicals used in this study were of analytical grade and purchased from S.D. Fine Chemicals, Mumbai. Silica coated TLC plates $(20 \times 20 \mathrm{~cm})$ were procured from Sigma-Aldrich, Hyderabad, India.

Extraction and physico-chemical analysis of the oils of $L$. leucocephala and $P$. africana. Oil was extracted from $L$. leucocephala and $P$. africana using soxhlet extractor with $n$-hexane for $10 \mathrm{~h}$ (Ajayi et al., 2004). The extracted oils were immediately analyzed for iodine value, peroxide value, saponification value, acid value, refractive index and unsaponifiable matter by method described by AOAC (1984).

Fatty acid composition of the oils of $L$. leucocephala and $\boldsymbol{P}$. africana. The fatty acid profile of these seed oils were obtained as fatty acid methyl esters. These were prepared by using $2 \%$ sulphuric acid in methanol. Fatty acid methyl esters of the oils were prepared by refluxing the oils at $70{ }^{\circ} \mathrm{C}$ for $4 \mathrm{~h}$ in $2 \% \mathrm{H}_{2} \mathrm{SO}_{4}$ in methanol. The esters were extracted into ethyl acetate and washed free of acid and dried over anhydrous sodium sulphate. The dried esters were further concentrated using a rotary evaporator and finally analyzed using GC. This was carried out using an Agilent 6850 series gas chromatography equipped with FID detector. A DB- 225 capillary column was used with the injector and detector temperature maintained at $230{ }^{\circ} \mathrm{C}$ and $250{ }^{\circ} \mathrm{C}$, respectively with a split ratio of $50: 1$ and the carrier gas being nitrogen at a flow rate of $1.5 \mathrm{~mL} / \mathrm{min}$. The oven temperature was programmed at $160{ }^{\circ} \mathrm{C}$ for $2 \mathrm{~min}$ and finally increased to $230^{\circ} \mathrm{C}$ at $4{ }^{\circ} \mathrm{C} / \mathrm{min}$. The carrier gas was nitrogen at a flow rate of $1.5 \mathrm{~mL} / \mathrm{min}$. The area percentages were recorded with a standard Chemstation Data System.

Proximate analysis of the seeds of $L$. leucocephala and $P$. africana. Proximate analysis of the seeds of L. leucocephala and P. africana was carried out as described AOAC (1990).

Mineral determination in the seeds and oils of L. leucocephala and P. africana. Metals determined were lead, cadmium, copper, zinc, iron, magnesium, calcium, sodium, potassium and manganese. $0.5 \mathrm{~g}$ of the defatted seed samples as well as $0.5 \mathrm{~g}$ of the extracted seed oils were taken separately for analysis. This was achieved by digesting the samples using $5 \mathrm{~mL}(2: 1)$ of
$69.40 \% \mathrm{w} / \mathrm{w}$ nitric acid and $90.00 \% \mathrm{w} / \mathrm{w}$ perchloric acid (Oderinde et al., 2008). Briefly, the samples were digested using mixture of nitric and perchloric acids in ratio 2:1 in a digestion set up. This was heated until the sample (defatted seed or extracted seed oil) was completely digested, leading to the formation of a clear solution. The clear solution was transferred into a 50 $\mathrm{mL}$ standard flask and made up to mark using de-ionized water. These solutions were analyzed for metal content by atomic absorption spectrophotometry (Perkin-Elmer, GMBH, Ueberlingen, Germany).

Separation of the lipid classes of the oil seeds. Lipid classes were separated on a $1 \mathrm{~g}$ scale into neutral lipids, glycolipids and phospholipids by silica gel column chromatography using a glass column $20 \mathrm{~cm} \times 2 \mathrm{~cm}$ OD packed with $30 \mathrm{~g}$ activated silica gel (60-120 mesh). Neutral lipids, glycolipids and phospholipids were eluted successively using chloroform, acetone and methanol, respectively. The lipid fractions were screened by TLC for the identification of components using hexane - ethyl acetate $(90: 10, \mathrm{v} / \mathrm{v})$ as developing solvent for neutral lipids, chloroform-methanol-water (65: 25 $: 4, \mathrm{v} / \mathrm{v} / \mathrm{v})$ for glycolipids and chloroform-methanol acetic acid-water $(170: 25: 24: 4, \mathrm{v} / \mathrm{v} / \mathrm{v} / \mathrm{v})$ for phospholipids (Christie, 1982). The eluted spots were sprayed with resorcinol-sulphuric acid, ammonium molybdate, ninhydrin, $\alpha$-naphthol and Dragendorff spray reagents for further confirmation (Prabhakara $e t$ al., 2009). The individual fractions were distilled under vacuum to remove solvent and weighed for quantification. The individual lipid fractions were converted into fatty acid methyl esters by refluxing with $2 \%$ methanol sulphuric acid for $4 \mathrm{~h}$. The esters were extracted into ethyl acetate, washed with distilled water and dried over anhydrous sodium sulphate and the fatty acid profile analyzed using GC as described above.

Identification of unsaponifiable matters of L. leucocephala and P. africana. Oil (2g) was dissolved in $25 \mathrm{~mL}$ of $2 \mathrm{M}$ ethanolic potassium hydroxide and refluxed for $1 \mathrm{~h}$. The reaction mixture was later diluted to $150 \mathrm{~mL}$ with distilled water and transferred into a separating funnel. The unsaponifiable constituents were then extracted three times with $50 \mathrm{~mL}$ diethylether. The ether extract was first washed with $100 \mathrm{~mL}$ aqueous solution of $0.5 \mathrm{M}$ potassium hydroxide in order to remove any residual fatty acids. This was further washed and cleaned with distilled water until it was free of potassium hydroxide, dried over anhydrous sodium 
sulphate and concentrated using a rotary evaporator (Esuoso and Odetokun, 1995). The unsaponifiables were identified using a GC-MS. This was achieved using Agilent (Palo Alto, USA) 6890N gas chromatography equipped with an HP-1 MS capillary column connected to an Agilent 5973 mass spectrometer operating in the EI mode (70ev; m/z 50-550; source temperature $230{ }^{\circ} \mathrm{C}$ and quadruple temperature $150{ }^{\circ} \mathrm{C}$ ). Structural assignments were made based on interpretation of mass spectrometric fragmentation and confirmation by comparison of retention time as well as fragmentation pattern of authentic compounds and the spectral data obtained from the Wiley and NIST Libraries.

Statistical analysis. All data were analyzed by oneway ANOVA $(\mathrm{P}<0.05)$ and least significant differences between treatment means were determined by Duncan's multiple range test $(\mathrm{P}<0.05)($ Duncan, 1955).

\section{Results and Discussion}

Proximate composition of the seeds of $L$. leucocephala and $\boldsymbol{P}$. africana. The proximate composition of the seeds of $L$. leucocephala and $P$. africana is presented in Table 1. The protein and carbohydrate content of the seeds are high. Protein was found to be $45.40 \pm 0.60 \mathrm{~g} /$ $100 \mathrm{~g}$ of seed in L. leucocephala and $40.20 \pm 0.80 \mathrm{~g} / 100$ $\mathrm{g}$ of seed in $P$. africana while the carbohydrate content was $38.20 \pm 0.30 \mathrm{~g} / 100 \mathrm{~g}$ of seed in L. leucocephala and $42.92 \pm 0.40 \mathrm{~g} / 100 \mathrm{~g}$ of seed in P. africana. The oil content of $L$. leucocephala $(6.80 \pm 0.71 \mathrm{~g} / 100 \mathrm{~g}$ of seed $)$ is higher than that of $P$. africana $(4.22 \pm 0.40 \mathrm{~g} / 100 \mathrm{~g}$ of seed). The crude fibre was found to be $4.10 \pm 0.50$ $\mathrm{g} / 100 \mathrm{~g}$ of seed in L. leucocephala and $5.50 \pm 0.15$ $\mathrm{g} / 100 \mathrm{~g}$ of seed in P. africana. The ash content as well as the moisture content of $P$. africana $(4.16 \pm 0.60 \mathrm{~g} / 100$ $\mathrm{g}$ of seed and $3.00 \pm 0.40 \mathrm{~g} / 100 \mathrm{~g}$ of seed, respectively)

Table 1. Proximate composition of the seeds of $L$. leucocephala and P. africana

\begin{tabular}{|c|c|c|}
\hline \multirow[t]{2}{*}{ Assay } & L. leucocephala & P. africana \\
\hline & \multicolumn{2}{|c|}{$(g / 100 g$ of seed) } \\
\hline Crude fat & $6.80 \pm 0.71$ & $4.22 \pm 0.40$ \\
\hline Crude protein & $45.40 \pm 0.60$ & $40.20 \pm 0.80$ \\
\hline Crude fibre & $4.10 \pm 0.50$ & $5.50 \pm 0.15$ \\
\hline Ash & $3.40 \pm 0.30$ & $4.16 \pm 0.60$ \\
\hline Moisture & $2.10 \pm 0.20$ & $3.00 \pm 0.40$ \\
\hline Carbohydrate & $38.20 \pm 0.30$ & $42.92 \pm 0.40$ \\
\hline
\end{tabular}

Values are mean \pm standard deviation of triplicate determinations were found higher than those of L. leucocephala $(3.40$ $\pm 0.30 \mathrm{~g} / 100 \mathrm{~g}$ of seed and $2.10 \pm 0.20 \mathrm{~g} / 100 \mathrm{~g}$ of seed, respectively).

Physico-chemical characterization of the oils from L. leucocephala and P. africana. The oil of $L$. leucocephala was light yellow in colour while that of P. africana was golden yellow as shown in Table 2. The acid value of $P$. africana $(12.25 \pm 0.20 \mathrm{mgKOH} / \mathrm{g})$ was higher than that of L. leucocephala $(8.30 \pm 0.50 \mathrm{mg}$ $\mathrm{KOH} / \mathrm{g}$ ). The saponification values of $L$. leucocephala and $P$. africana were found to be $188.60 \pm 1.00 \mathrm{mg}$ $\mathrm{KOH} / \mathrm{g}$ and $186.20 \pm 0.80 \mathrm{mg} \mathrm{KOH} / \mathrm{g}$, respectively. The iodine value which reflects the unsaturation of these oils was found to be $113.00 \pm 2.10 \mathrm{~g} / 100 \mathrm{~g}$ in $L$. leucocephala and $118.30 \pm 1.00 \mathrm{~g} / 100 \mathrm{~g}$ in P. africana. This high unsaturation of the oil was also noticed in their state at room temperature as they exist as liquid. The unsaponifiable matter of $L$. leucocephala was 0.86 $\pm 0.30 \%$ while that of $P$. africana was $1.01 \pm 0.50 \%$.

Lipid classes of the oils from L. leucocephala and P. africana. The oils from L. leucocephala and P. africana were separated into neutral, glyco and phospholipids on a $1 \mathrm{~g}$ scale using column chromatography. The dominant

Table 2. Physico-chemical characterization of the oils from L. leucocephala and P. africana

\begin{tabular}{lll}
\hline \hline Parameters & \multicolumn{2}{l}{ L. leucocephala P. africana } \\
\hline Colour & Light yellow & Golden yellow \\
Acid value $(\mathrm{mgKOH} / \mathrm{g})$ & $8.30 \pm 0.50$ & $12.25 \pm 0.20$ \\
Free fatty acid $(\%)$ & $4.20 \pm 0.10$ & $6.20 \pm 0.30$ \\
Saponification value $(\mathrm{mgKOH} / \mathrm{g})$ & $188.60 \pm 1.00$ & $186.20 \pm 0.80$ \\
Iodine value $(\mathrm{g} / 100 \mathrm{~g})$ & $113.00 \pm 2.10$ & $118.30 \pm 1.00$ \\
Unsaponifiable $\mathrm{matter}(\%)$ & $0.86 \pm 0.30$ & $1.01 \pm 0.50$ \\
Peroxide value $\left(\mathrm{mgO}_{2} / \mathrm{g}\right.$ oil $)$ & $1.00 \pm 0.10$ & $3.50 \pm 0.50$ \\
Refractive index $\left(25^{\circ} \mathrm{C}\right)$ & $1.4570 \pm 0.10$ & $1.4330 \pm 0.08$ \\
Specific gravity $\left(25^{\circ} \mathrm{C}\right)$ & $0.9760 \pm 0.03$ & $0.9340 \pm 0.06$ \\
State at room temperature & Liquid & Liquid \\
\hline \hline
\end{tabular}

Values are mean \pm standard deviation of triplicate determinations

Table 3. Lipid classes of the oils from L. leucocephala and $P$. africana

\begin{tabular}{lll}
\hline \hline Parameters & \multicolumn{1}{c}{ L. leucocephala } & P. africana \\
\cline { 2 - 3 } & \multicolumn{1}{c}{$(\mathrm{g} / 100 \mathrm{~g}$ of oil) } \\
\hline Neutral lipids & $83.70 \pm 0.20$ & $90.10 \pm 0.50$ \\
Glycolipids & $10.30 \pm 0.50$ & $9.70 \pm 1.10$ \\
Phospholipids & $6.00 \pm 0.10$ & $0.20 \pm 0.50$ \\
\hline \hline
\end{tabular}

Values are mean \pm standard deviation of duplicate determinations. 
lipid class was found to be the neutral lipids as shown in Table 3. The neutral lipids of $L$. leucocephala was found to be $83.70 \pm 0.20 \mathrm{~g} / 100 \mathrm{~g}$ of oil while that of P. africana was found to be $90.10 \pm 0.50 \mathrm{~g} / 100 \mathrm{~g}$ of oil. Glycolipids were found to be $10.30 \pm 0.50 \mathrm{~g} / 100 \mathrm{~g}$ of oil in L. leucocephala and $9.70 \pm 1.10 \mathrm{~g} / 100 \mathrm{~g}$ of oil in P. africana. Phospholipids were accumulated in higher amount in L. leucocephala $(6.00 \pm 0.10 \mathrm{~g} / 100 \mathrm{~g}$ of oil $)$ than in P. africana $(0.20 \pm 0.50 \mathrm{~g} /$ $100 \mathrm{~g}$ of oil).

Fatty acid composition of the oils of $L$. leucocephala and $\boldsymbol{P}$. africana. The fatty acid composition of the oils of L. leucocephala and $P$. africana is presented in Table 4. Palmitic (C16:0), oleic (C18:1) and linoleic (C18:2) acids are present in these oils at a concentration above $20 \mathrm{~g} / 100 \mathrm{~g}$ of methyl ester except for palmitic acid which is $16.70 \pm 0.30 \mathrm{~g} / 100 \mathrm{~g}$ of methyl ester in $P$. africana. Linoleic acid is predominantly present in L. leucocephala $(37.90 \pm 0.20 \mathrm{~g} / 100 \mathrm{~g}$ of methyl ester) while oleic was found predominantly in $P$. africana $(42.00 \pm 0.50 \mathrm{~g} / 100 \mathrm{~g}$ of methyl ester). Linolenic was found in small amount in both oils; it was found to be $1.70 \pm 0.10 \mathrm{~g} / 100 \mathrm{~g}$ of methyl ester in L. leucocephala and $0.50 \pm 0.30 \mathrm{~g} / 100 \mathrm{~g}$ of methylester in P. africana. C24:1 was found to be $0.5 \pm 0.30 \mathrm{~g} / 100 \mathrm{~g}$ of methyl ester in L. leucocephala but it was not detected in $P$. africana. The unsaturation of $P$. africana $(73.30 \mathrm{~g} / 100$ $\mathrm{g}$ of methyl ester) is higher than that of $L$. leucocephala $(66.30 \mathrm{~g} / 100 \mathrm{~g}$ of methyl ester). This high unsaturation of $P$. africana was also noticed in the iodine value of the oil which was also found higher in P. africana than in L. leucocephala.

Fatty acid distribution in the lipid classes of $\boldsymbol{L}$. leucocephala and P. africana. The distribution of the fatty acids varies across the different lipid classes as presented in Table 5. Linoleic acid which is the dominant fatty acid

Table 4. Fatty acid composition of $L$. leucocephala and $P$. africana seed oils

\begin{tabular}{|c|c|c|}
\hline \multirow[t]{2}{*}{ Fatty acids } & L. leucocephala & P. africana \\
\hline & \multicolumn{2}{|c|}{ (g/100g of methyl esters) } \\
\hline $16: 0$ & $23.40 \pm 0.50$ & $16.70 \pm 0.30$ \\
\hline $16: 1$ & $3.40 \pm 0.30$ & $1.80 \pm 0.20$ \\
\hline $18: 0$ & $5.60 \pm 0.10$ & $7.30 \pm 0.10$ \\
\hline $18: 1$ & $22.50 \pm 0.50$ & $42.00 \pm 0.50$ \\
\hline $18: 2$ & $37.90 \pm 0.20$ & $28.80 \pm 0.30$ \\
\hline $18: 3$ & $1.70 \pm 0.10$ & $0.50 \pm 0.30$ \\
\hline 20:0 & $1.20 \pm 0.10$ & $1.30 \pm 0.60$ \\
\hline $20: 1$ & $0.30 \pm 0.30$ & $0.20 \pm 0.20$ \\
\hline $22: 0$ & $2.00 \pm 0.10$ & $0.70 \pm 0.20$ \\
\hline $24: 0$ & $1.50 \pm 0.50$ & $0.70 \pm 0.25$ \\
\hline $24: 1$ & $0.5 \pm 0.30$ & ND \\
\hline Unsaturated & 66.30 & 73.30 \\
\hline Saturated & 33.70 & 26.70 \\
\hline
\end{tabular}

Values are mean \pm standard deviation of duplicate determinations. $\mathrm{ND}=$ Not Detected

Table 5. Fatty acid distribution in the lipid classes of L. leucocephala and P. africana

\begin{tabular}{|c|c|c|c|c|c|c|}
\hline \multirow{3}{*}{ Fatty acids } & \multicolumn{3}{|c|}{ L. leucocephala } & \multicolumn{3}{|c|}{ P. africana } \\
\hline & NL & GL & PL & NL & GL & PL \\
\hline & \multicolumn{3}{|c|}{ (g/100g of methyl ester) } & \multicolumn{3}{|c|}{ (g/100g of methyl ester) } \\
\hline $16: 0$ & $24.0 \pm 0.2$ & $21.8 \pm 0.5$ & $24.7 \pm 0.1$ & $17.3 \pm 0.1$ & $20.7 \pm 0.1$ & $60.4 \pm 0.2$ \\
\hline $16: 1$ & $3.6 \pm 1.0$ & $5.1 \pm 0.4$ & $1.4 \pm 0.5$ & $1.8 \pm 0.6$ & $2.1 \pm 0.0$ & $0.3 \pm 0.5$ \\
\hline $18: 0$ & $5.8 \pm 0.2$ & $3.5 \pm 0.1$ & $4.4 \pm 0.3$ & $7.7 \pm 0.5$ & $1.8 \pm 0.2$ & $8.8 \pm 0.2$ \\
\hline $18: 1$ & $23.1 \pm 0.5$ & $19.5 \pm 0.2$ & $15.9 \pm 01$ & $42.2 \pm 0.1$ & $42.1 \pm 0.5$ & $15.9 \pm 0.1$ \\
\hline $18: 2$ & $37.3 \pm 0.5$ & $27.1 \pm 0.1$ & $51.1 \pm 0.1$ & $27.4 \pm 0.5$ & $27.4 \pm 0.2$ & $8.8 \pm 0.6$ \\
\hline $18: 3$ & $1.4 \pm 0.3$ & $1.8 \pm 0.7$ & $2.0 \pm 0.5$ & $0.4 \pm 0.1$ & $0.5 \pm 0.2$ & ND \\
\hline $20: 0$ & $1.2 \pm 0.1$ & $0.7 \pm 0.1$ & $0.5 \pm 0.1$ & $1.5 \pm 0.1$ & $1.6 \pm 0.1$ & $2.0 \pm 0.5$ \\
\hline $20: 1$ & $0.3 \pm 0.5$ & ND & ND & $0.2 \pm 0.5$ & $0.3 \pm 0.5$ & $0.4 \pm 0.1$ \\
\hline $22: 0$ & $1.7 \pm 0.6$ & $2.7 \pm 0.5$ & ND & $0.9 \pm 0.2$ & $1.0 \pm 0.1$ & $2.5 \pm 0.2$ \\
\hline $24: 0$ & $1.4 \pm 0.1$ & $9.3 \pm 0.8$ & ND & $0.6 \pm 0.2$ & $2.5 \pm 0.2$ & $0.9 \pm 0.2$ \\
\hline $24: 1$ & $0.2 \pm 0.3$ & $8.5 \pm 0.2$ & ND & ND & ND & ND \\
\hline Unsaturated & 65.9 & 62.0 & 70.4 & 72.0 & 72.4 & 25.4 \\
\hline Saturated & 34.1 & 38.0 & 29.6 & 28.0 & 27.6 & 74.6 \\
\hline
\end{tabular}

Values are mean \pm standard deviation of duplicate determinations. ND $=$ Not Detected $\mathrm{NL}=$ Neutral lipids, GL $=$ Glycolipids, $\mathrm{PL}=$ Phospholipids 
in the total lipid of L. leucocephala was found to be dominantly present in the phospholipid where it was found to be $51.1 \pm 0.1 \mathrm{~g} / 100 \mathrm{~g}$ of methyl ester. Palmitic acid was distributed almost in equal amount across the lipid classes of L. leucocephala. It was found to be $24.0 \pm 0.2 \mathrm{~g} / 100$ $\mathrm{g}$ of methyl ester in the neutral lipids, $21.8 \pm 0.5 \mathrm{~g} / 100 \mathrm{~g}$ of methyl ester in the glycolipids and $24.7 \pm 0.1 \mathrm{~g} / 100 \mathrm{~g}$ of methyl ester in the phospholipids. In P. africana, palmitic acid was accumulated high in the phospholipids where it was found to be $60.4 \pm 0.2 \mathrm{~g} / 100 \mathrm{~g}$ of methyl ester. Oleic was found to be $42.2 \pm 0.1 \mathrm{~g} / 100 \mathrm{~g}$ of methyl ester in the neutral lipids, $42.1 \pm 0.5 \mathrm{~g} / 100 \mathrm{~g}$ of methyl ester in glycolipids and $15.9 \pm 0.1 \mathrm{~g} / 100 \mathrm{~g}$ of methyl ester in the phospholipids. Linolenic acid was not found in the

Table 6. Unsaponifiable composition of $L$. leucocephala and $P$. africana seed oil

\begin{tabular}{ll}
\hline \hline L. leucocephala & P. africana \\
\hline Dodecane & Tridecane \\
Tetradecane & Nonadecane \\
Hexadecane & Tetradecane \\
Octadecane & Hexadecane \\
Docosane & Pentadecane \\
Heptadecane & Hexadecene \\
Stigmasterol & Heptadecane \\
Octadecene & Eicosene \\
- & Nonadecene \\
- & Pentadecene \\
- & Sitosterol \\
- & Stigmasterol \\
\hline \hline
\end{tabular}

phospholipids of $P$. africana but it was found to be $0.4 \pm$ $0.1 \mathrm{~g} / 100 \mathrm{~g}$ of methyl ester in the neural lipids and $0.5 \pm$ $0.2 \mathrm{~g} / 100 \mathrm{~g}$ of methyl ester in the glycolipids. C20:1 was only detected in the neutral lipids of L. leucocephala to be $0.3 \pm 0.5 \mathrm{~g} / 100 \mathrm{~g}$ of methyl ester; it was not detected in the glycolipids and phospholipids. C22:0, C24:0 and C24:1 were not detected in the phospholipids of L. leucocephala but in the neutral and glycolipids. The unsaturation was found to have increased in the phospholipids of L. leucocephala $(70.4 \mathrm{~g} / 100 \mathrm{~g}$ of methyl ester) but decreased in the phospholipids of $P$. africana $(25.4 \mathrm{~g} / 100 \mathrm{~g}$ of methyl ester). On the other hand the saturation of the oils decreased in the phospholipids of L. leucocephala ( $29.6 \mathrm{~g} / 100 \mathrm{~g}$ of methyl ester) where as it increased in the phospholipids of $P$. africana $(74.6 \mathrm{~g} /$ $100 \mathrm{~g}$ of methyl ester).

Identification of unsaponifiables in the oils of L. leucocephala and P. africana. The GC-MS results of the unsaponifiable matter of $L$. leucocephala and $P$. africana revealed the presence of stigmasterol in L. leucocephala and $P$. africana (Table 6). Other substances present in both L. leucocephala and P. africana includes; tetradecane, hexadecane and heptadecane. Dodecane and octadecane were found in L. leucocephala while $P$. africana contains tridecane, nonadecane, pentadecane, hexadecane, eicosene, nonadecene and pentadecene.

Nutritionally valuable and trace metals of L. leucocephala and P. africana. The results of the nutritionally valuable and trace metals of $L$. leucocephala and $P$. africana are presented in Table 7. Minerals were

Table 7. Nutritionally valuable and trace metals of the seeds and oils of $L$. leucocephala and P. africana

\begin{tabular}{llllll}
\hline \hline & \multicolumn{2}{c}{ Seed } & \multicolumn{2}{c}{ Oil } \\
\cline { 2 - 3 } Metals & L. leucocephala & P. africana & & L. leucocephala & P. africana \\
\cline { 2 - 3 } \cline { 6 - 6 } & \multicolumn{2}{c}{$(\mathrm{ppm})$} & & \multicolumn{2}{c}{ (ppm) } \\
\hline $\mathrm{Na}$ & $560.40 \pm 0.40$ & $560.20 \pm 0.50$ & & $382.10 \pm 0.50$ & $482.50 \pm 0.30$ \\
$\mathrm{~K}$ & $970.20 \pm 1.10$ & $882.00 \pm 0.40$ & & $850.70 \pm 0.50$ & $811.30 \pm 0.50$ \\
$\mathrm{Ca}$ & $420.20 \pm 0.50$ & $450.40 \pm 0.30$ & & $350.50 \pm 0.20$ & $352.40 \pm 0.10$ \\
$\mathrm{Mg}$ & $280.40 \pm 1.20$ & $135.40 \pm 0.30$ & & $210.10 \pm 0.50$ & $88.10 \pm 0.50$ \\
$\mathrm{Fe}$ & $322.50 \pm 0.20$ & $98.40 \pm 0.20$ & & $281.20 \pm 0.80$ & $52.20 \pm 0.10$ \\
$\mathrm{Cu}$ & $1.20 \pm 0.50$ & $0.50 \pm 0.20$ & & $0.50 \pm 0.20$ & $0.10 \pm 0.50$ \\
$\mathrm{Zn}$ & $120.45 \pm 1.00$ & $58.00 \pm 0.20$ & & $95.50 \pm 0.40$ & $35.20 \pm 0.50$ \\
$\mathrm{Mn}$ & $45.20 \pm 0.40$ & $82.00 \pm 0.30$ & & $29.10 \pm 0.20$ & $65.30 \pm 0.10$ \\
$\mathrm{~Pb}$ & $1.20 \pm 0.20$ & $0.20 \pm 0.20$ & & $0.10 \pm 0.10$ & $0.01 \pm 0.50$ \\
$\mathrm{Cd}$ & $0.10 \pm 0.20$ & $0.10 \pm 0.10$ & & ND & $\mathrm{ND}$ \\
\hline \hline $\mathrm{Av}$ & & & &
\end{tabular}

Average concentration \pm standard deviation of triplicate determinations $(\mathrm{ppm})(\mathrm{mg} / \mathrm{kg})$

ND; Not detected. 
determined in the seeds and oils of L. leucocephala and $P$. africana using atomic absorption spectro-photometer. Seeds and oils have the highest value of K. Na was found to be $560.40 \pm 0.40$ and $560.20 \pm 0.50 \mathrm{ppm}$ in the seeds of L. leucocephala and P. africana. It was also found to be $382.10 \pm 0.50$ in the oil of L. leucocephala and $482.50 \pm 0.30 \mathrm{ppm}$ in the oil of $P$. africana. Ca was found higher in the seed (450.40 $\pm 0.30 \mathrm{ppm})$ and oil $(352.40 \pm 0.10 \mathrm{ppm})$ of $P$. africana. Trace metals were found in low concentration in both the seeds and oils. $\mathrm{Cu}$ was found to be $1.20 \pm 0.50 \mathrm{ppm}$ in the seed of L. Leucocephala and $0.50 \pm 0.20 \mathrm{ppm}$ in the seed of $P$. africana. The concentration of this trace metal was found lower in the oils than the seeds showing that small amount was extracted along with the oil. $\mathrm{Pb}$ was found to be $1.20 \pm 0.20 \mathrm{ppm}$ in the seed of L. leucocephala and $0.20 \pm 0.20 \mathrm{ppm}$ in the seed of $P$. africana. Cd was detected to be $0.10 \pm 0.20 \mathrm{ppm}$ and $0.10 \pm 0.10 \mathrm{ppm}$ in the seeds of L. leucocephala and P. africana, respectively. Cd was not detected in the oils of L. leucocephala and P. africana which shows that the metal was not extracted along with the oils.

\section{Conclusion}

The study has revealed the chemical composition, mineral and fatty acid distribution of the seeds and oils of L. leucocephala and P. africana from Nigeria. K was found to be most abundant in the seed as well as the oils of L. leucocephala and P. africana while the dominant fatty acid of the oils was found to be linoleic (C18:2) in L. leucocephala and oleic (C18:1) in P. africana.

\section{Acknowledgement}

Adewuyi Adewale thanks the Third World Academy of Sciences (TWAS) for awarding the research fellowship for carrying out this work at India Institute of Chemical Technology (IICT) and also grateful to Dr J. S. Yadav, Director, IICT for his support and encouragement.

\section{References}

Ajayi, I. A., Dawodu, F. A., Adebowale, K. O., Oderinde, R. A. 2004. A study of the oil content of Nigerian grown Monodora myristica seeds for its nutritional and industrial application. Pakistan Journal of Scientific and Industrial Research, 47: 60-65.

Akoh, C.C., Min, DB. 2002. Food Lipids - Chemistry, Nutrition, and Biochemistry, $2^{\text {nd }}$ edition, Marcel, New York, USA.

AOAC. 1990. Official Methods of Analysis, $15^{\text {th }}$ edition, pp.770-771. Association of Official Analytical Chemists, Inc., Virginia, USA.

AOAC, 1984. Official Methods of Analysis, $14^{\text {th }}$ edition, Vol. 67, pp. 503-515. Association of Official Analytical Chemist, Inc., Virginia, USA.

Burkill, H.M. 1995. The Useful Plants of West Tropical Africa. $2^{\text {nd }}$ edition, Vol. 3, pp. 237-238, Royal Botanic Gardens.

Christie, W.W. 1982. Lipid Analysis, $2^{\text {nd }}$ edition, 107 pp., Pergamon Press.

Duncan, D.B. 1955. Multiple range and multiple T tests, Biometrics, 2: 1- 42.

Esuoso, K.O., Odetokun, S.M. 1995. Proximate composition and possible industrial utilization of chemical Blighia sapida seed and seed oils. Larivista Italiana Delle Sostanze Grasse, 72: 311-313.

Frank, D.G. 2004. The Chemistry of Oils and Fats: Sources, Composition, Properties and Uses, pp. 1-2. Blackwell Publishing Ltd.

Oderinde, R.A., Adewuyi, A., Ajayi, I.A. 2008. Determination of the mineral nutrients, characte-rization and analysis of the fat-soluble vitamins of Caesalpinia pulcherrima and Albizia lebbeck seed and seed oils. Seed Science and Biotechnology, 2: 74-78.

Prabhakara, R.P.G., Narsing, R.G., Jyothirmayi, T., Karuna, M.S.L., Prasad, R.B.N. 2009. Analysis of lipid classes and fatty acid composition of Jangle Jalebi (Pithecellobium dulce L.) seed oil. Journal of Lipid Science and Technology, 41: 5-7. 